\title{
Gender differences in sexual behaviour amongst university students in Mahikeng, South Africa
}

\author{
Akim J Mturi" and Lucia Gaearwe \\ Research Niche Area 'Population and Health' \\ Faculty of Human and Social Sciences \\ North-West University (Mafikeng Campus) \\ akimmturi@gmail.com
}

\begin{abstract}
Studies indicate that females are more prone to the consequences of 'irresponsible' sexual activities than males on university campuses. This paper presents gender differences in sexual behaviour among students on a university campus. Data were collected from I,060 students (45I males and 609 females). Multivariate data analysis included both multiple OLS regression and multinomial logistic regression. The results show that the proportion of virgin females was twice as much as males. The average age at first sexual intercourse was higher for females (18 years) than males (16 years). The analysis also shows that gender and year of study are significant determinants of age at first sex. Moreover, in a multivariate perspective, males are less likely to indulge in risky sexual activities compared to their female counterparts. It is recommended that the HIV/AIDS programme on campus should focus on ways to minimize 'irresponsible' sexual activities and put more emphasis on females.
\end{abstract}

Keywords: Gender; University students; Sexual behaviour; HIV/AIDS; STIs; South Africa

\section{Résumé}

Des études montrent que les femmes sont plus sujettes aux conséquences des activités sexuelles "irresponsables" que les hommes sur les campus universitaires. Cet article présente les différences entre les sexes dans les comportements sexuels parmi les étudiants sur le campus universitaire de Mahikeng, en Afrique du Sud. Les données ont été recueillies auprès de 1060 étudiants (45I hommes et 609 femmes). L'analyse multi variée des données comprenait à la fois multiple régression $M C O$ et la régression logistique multinomiale. Les résultats obtenus ont montré que la proportion de filles vierges était deux fois plus que chez les hommes. L'âge moyen au premier rapport sexuel était plus élevé pour les filles (I8 ans) que chez les hommes (16 ans). L'analyse a démontré également que le sexe et l'année d'étude sont des facteurs importants déterminant l'âge lors du premier rapport sexuel. En outre, dans une perspective multi variée, les hommes sont moins susceptibles de se livrer à des activités sexuelles à risque par rapport à leurs homologues féminins. Il est recommandé que le programme VIH / SIDA sur le campus devrait se concentrer sur les moyens de réduire au minimum les activités sexuelles "irresponsables" et de mettre davantage l'accent sur les femmes.

Mots clé: genre;les étudiants de l'Université; le comportement sexuel; le $\mathrm{VIH} /$ sida, les IST; I'Afrique du Sud

\footnotetext{
* Corresponding Author
} 


\section{Introduction}

Many young people separate from their parents for the first time when they join the university. They join other people of same and different sex from different backgrounds on campuses without the supervision they are used to at home. This is the time a lot of things happen. One area that has been discussed in the literature is to do with sexual activities on university campuses (Anyanwu et al., 2013; Hoque, 20II; Kabir et al, 2004; Ngoma and Himooya, 2010; Ojedokun and Balogun, 2008; Omoteso, 2006). Social parties associated with excessive alcohol drinking, drugs and peer pressure are some of the factors exacerbating sexual activities on campuses (Gilchrist et al., 2012; Olley, 2008). Many consequences of sexual activities have been noted such as unplanned pregnancies, HIV/AIDS, induced abortions and some students even drop-out of studies (Kabir et al., 2004; Omoteso, 2006). Unfortunately females are more prone to the consequences than males especially in South Africa (O'Sullivan, 2006), but the gender differences in sexual activities on campuses are not very clear.

This paper compares sexual activities of male and female students on a university campus. The factors influencing their sexual experiences are also investigated by gender. The specific objectives of this study are to:-

I. Examine the characteristics of male and female university students who have never had sexual intercourse;

2. Assess the factors associated with age at first intercourse for males and females; and

3. Examine factors associated with risky sexual behavior and whether they are different for male and female students.

\section{Literature Review}

Studies indicate that some students continue to remain virgins at university campuses despite the predisposing factors mentioned above. Anyanwu et al. (2013) found that only $18 \%$ of the sampled students at the University of Venda never had sexual intercourse. But the gender disparities were enormous. Whilst only $9.9 \%$ of males were still virgin, $27.7 \%$ of females were virgins. The picture observed by Hoque et al. (20II) in their study at the University of Botswana showed that $36.1 \%$ (30.6\% of males and $38.7 \%$ of females) had never had sexual intercourse. Although the University of Venda and the University of Botswana are situated in different countries, the magnitude of the gap needs better understanding of this phenomenon. In fact the opposite is expected since the University of Botswana is an urban university and the University of Venda is situated in a rural setting. One point is clear from this comparison - more research is needed to shed more light on sexual activities on university campuses.

Another factor that has been discussed in the literature is the age at first sexual intercourse and the situation under which sexual debut is taking place. This is important because there is a strong association between age at first intercourse and subsequent sexual health (Gueye et al.200I). Anyanwu et al. (2013) reported that at the University of Venda, average age at first intercourse was 17.5 years ( 16.7 years for males and 18.4 years for females). This finding is supported by Hoque et al. (20I I) who found that males started to have sex earlier (16.5 years) than females (I8.I years). However, Fisher (2007) found younger age at first sexual intercourse among female college students compared to males in the US. Haggstrom-Nordin et al. (2002) did not find any significant gender differences among Swedish high school students with regard to age at first intercourse. The reasons for initiating first sex vary by sex, residence and other characteristics. For instance, Gueye et al. (200I) in their survey of adolescents identified in households in Mali, showed that the majority of young males gave reasons for initiating first sexual intercourse to include curiosity, peer pressure and love (in that order) whilst females reported to be love, promise of marriage and marital duty.

Sexual activity on university campuses has attracted many researchers mainly because of its relationship with sexually transmitted infections (STIs) including HIV/AIDS. This is due to the fact that students indulge in risky sexual behaviour such as having multiple sexual partners, not using condoms or irregular use of condoms, having transactional sex, etc (Njikam-Savage, 2005). Students at the University of Zambia, for example, reported that $65 \%$ of females and $50 \%$ of males used a condom in the last sexual act (Ngoma and Himoonga, 2010). At the University of Botswana it was $93 \%$ of males and $85 \%$ of females (Hoque et al., 20I2) and at the University of Venda it was 74\% of males and $64 \%$ of females (Anyanwu et al., 20I3). Except for the University of Botswana, the other two universities show that use of condoms is low 
among both female and male students. The University of Venda study went further to show that a total of $14 \%$ of sexually active students did not use a condom properly during the last sexual act (Anyanwu et al., 2013). This has a lot of implications on acquiring STls and getting (or making one) pregnant. Having multiple sexual partners is also not uncommon on university campuses (Letamo, 201 I; Ngoma and Himoonga, 2010; Hoque et al., 2012; Anyanwu et al., 2013).

A study done in Nigeria among selected university undergraduate students at the Olabisi Onabanjo University revealed that premarital sexual permissiveness attitudes were favourable among male students than female students (Ojedokun and Balogun, 2008). In general, both male and female students living alone reported significant favourable attitudes towards premarital sexual permissiveness than their counterparts living with fellow students. However, under the same living arrangements, male students reported significant attitudes towards premarital sexual permissiveness than female students. In addition, in both cases students living with parents and guardians reported the least favourable attitudes towards premarital sexual permissiveness (Ojedokun and Balogun, 2008). The results of this study concur with Amoateng and Kalule-Sabiti's (2013) household study which showed the impact on parental control on sexual behaviours among adolescents in the population.

To conclude, the studies cited above show that there is still a lot of room on improving sexual activities among university students. This study tries to make a contribution in this regard by looking closely at the gender disparities.

\section{Data Source and Methods}

A quantitative cross-sectional survey was conducted at the North-West University, Mafikeng Campus (NWU_MC) from May to September 2013.The NWU_MC (formerly known as University of NorthWest) is the only campus that has university students in Mahikeng, the capital city of the North-West province. The choice of this campus is determined by not only its proximity to the researchers, but also not much has been documented on understanding sexual behaviour of the students despite the fact that the negative consequences are many. A representative sample of 1,060 respondents was selected using cluster sampling where the five academic faculties were treated as clusters. Data were collected using a self-administered structured questionnaire.

Data analysis was divided into three parts. The first part of analysis was done for respondents who never had sex. The characteristics of male and female students were explored using descriptive statistics. The second analysis was done on age at first sex and the circumstances under which first intercourse took place for those who were sexually experienced. The factors associated with age at first intercourse are analysed using multiple OLS regression since the dependent variable is a continuous variable. The independent variables include faculty registered and year of study, use of condom, alcohol usage, type of relationship with partner, exchange of rewards, whether friends are sexually active or not, and survival status of biological parents.

The third part of analysis was done based on the recent information on risk sexual activities. A composite variable on risky sexual behaviour was created with three categories namely 'no risk', 'low risk', and 'high risk' (Khasakhala and Mturi, 2008; Zambuko and Mturi, 2005). The multinomial logistic regression was used to investigate the factors associated with risky sexual behaviour of male and female university students. The independent variables included background characteristics of respondents (e.g. age, faculty and year of study, household size and composition, etc.), type of place of residence of home, residence at the university and survival status of biological parents.

There was one limitation of this study that needs to be stated. There was no method used to verify the information provided by the respondents. This implies that if the respondent was lying, the research team were not able to verify this. The instructions given before the questionnaires were distributed appealed to the respondents to give accurate information but there was still a chance for a few to exaggerate their responses. There is a need therefore to be cautious in interpreting the findings.

The characteristics of respondents are presented in Table I. The total sample was I,060 of which $42.5 \%$ were males and $57.5 \%$ females. The mean age of respondents was 22 years for both male and female respondents and the majority were under 24 years of age. The distribution of respondents by year of study reflects the actual distribution of students where there were fewer postgraduate students compared with individual years for undergraduates. 
Unfortunately there were fewer respondents from the Faculty of Education than anticipated. The distribution by the home town/village shows that there were more students residing in rural areas (57.6\%) compared to those in urban areas (42.4\%). This is understandable since NWU_MC is classified as a rural campus. As expected, many respondents (47.5\%) live on campus but there was a substantial number of them either renting a room off campus or having alternative accommodation elsewhere. The table shows that $63 \%$ of the respondents had both parents alive whereas $37 \%$ had either one or both parents dead.

Table I: Percentage distribution of respondents

\begin{tabular}{|c|c|c|c|}
\hline Characteristics & Male & Female & Total \\
\hline $\begin{array}{l}\text { Age } \\
18-20 \\
21-23 \\
24+ \\
\text { Mean } \\
\text { S.D. }\end{array}$ & $\begin{array}{l}37.7 \\
46.6 \\
15.7 \\
\\
21.9 \\
3.59\end{array}$ & $\begin{array}{l}47.3 \\
37.9 \\
14.8 \\
\\
21.8 \\
4.00\end{array}$ & $\begin{array}{l}43.2 \\
41.6 \\
15.2 \\
21.8 \\
3.83\end{array}$ \\
\hline $\begin{array}{l}\text { Year of study } \\
\text { First year } \\
\text { Second year } \\
\text { Third year } \\
\text { Postgraduate }\end{array}$ & $\begin{array}{l}38.1 \\
22.8 \\
23.5 \\
15.5\end{array}$ & $\begin{array}{l}33.0 \\
23.5 \\
29.6 \\
14.0\end{array}$ & $\begin{array}{l}35.2 \\
23.2 \\
27.0 \\
14.6\end{array}$ \\
\hline $\begin{array}{l}\text { Faculty } \\
\text { Human \& Social Sciences } \\
\text { Agriculture, Science \& } \\
\text { Technology } \\
\text { Commerce } \\
\text { Education } \\
\text { Law }\end{array}$ & $\begin{array}{l}24.8 \\
22.6 \\
25.3 \\
11.5 \\
15.7\end{array}$ & $\begin{array}{l}37.1 \\
18.4 \\
19.7 \\
19.7 \\
14.6\end{array}$ & $\begin{array}{l}31.9 \\
20.2 \\
22.1 \\
10.8 \\
15.1\end{array}$ \\
\hline $\begin{array}{l}\text { Home residence } \\
\text { Rural } \\
\text { Urban }\end{array}$ & $\begin{array}{l}59.2 \\
40.8\end{array}$ & $\begin{array}{l}56.3 \\
43.7\end{array}$ & $\begin{array}{l}57.6 \\
42.4\end{array}$ \\
\hline $\begin{array}{l}\text { Residence at the university } \\
\text { On campus } \\
\text { Renting a room } \\
\text { Other }\end{array}$ & $\begin{array}{l}52.8 \\
15.3 \\
31.9\end{array}$ & $\begin{array}{l}43.7 \\
18.7 \\
37.6\end{array}$ & $\begin{array}{l}47.5 \\
17.3 \\
35.2 \\
\end{array}$ \\
\hline $\begin{array}{l}\text { Survival status of biological } \\
\text { parent } \\
\text { Both alive } \\
\text { Other }\end{array}$ & $\begin{array}{l}63.4 \\
36.6\end{array}$ & $\begin{array}{l}62.9 \\
37.1\end{array}$ & $\begin{array}{l}63.1 \\
36.9\end{array}$ \\
\hline Total & $\begin{array}{l}N=45 I \\
\%=100\end{array}$ & $\begin{array}{l}N=609 \\
\%=100\end{array}$ & $\begin{array}{l}N=1060 \\
\%=100\end{array}$ \\
\hline
\end{tabular}

Source: Mahikeng Sexual Behaviour Survey, 2013

\section{Results}

\section{Students who never had sex}

This section describes the characteristics of students who never had sexual intercourse. A total of 156 students ( $14.7 \%$ of the sample) reported that they were virgins at the time of interview. The proportion of females was two times higher (18.7\%) than that of males $(9.3 \%)$. This finding is very similar to that observed by Anyanwu et al. (2013) at the University of Venda. Table 2 presents characteristics of the respondents who never had sexual intercourse. These students were mainly young ( 20 years or younger), still doing their first year, home residence was in rural areas especially for males, and their biological parents were still alive. Apart from the gender disparities on type of place of residence, other characteristics do not show that much difference. Interestingly, two-thirds of these students reported that they were in a stable relationship with a member of the opposite sex at the time of the survey. Those who reported being in steady relationships indicated that their main sexual activity was hugging and kissing $(80.0 \%$ males and $66.7 \%$ females). There was a small group of respondents who reported that their relationship was only based on talking (13.3\% males and 19.7\% females). Most females reported that they had not initiated sex because they considered themselves to be young/not ready to have sex or they were waiting until they got married. Males cited culture/ religion and still being young as their main reasons for not initiating sex.

It can be concluded that there were more female university students who had never had sex compared to their male counterparts. Most of these students were 20 years old or younger and were doing first year of study. The analysis shows that males who have a rural background were more likely to be virgins than other students.

Table 2: Characteristics of respondents who never had sexual intercourse

\begin{tabular}{|l|c|c|c|}
\hline Characteristics & Male & Female & Total \\
\hline Age & & & \\
I8-20 & 54.8 & 73.7 & 68.6 \\
$21-23$ & 35.7 & 23.7 & 26.9 \\
$24+$ & 9.5 & 2.6 & 4.5 \\
\hline Year of study & & & \\
First year & 69.0 & 52.6 & 57.1 \\
Second year & 16.7 & 21.9 & 20.5 \\
Third year & 7.1 & 18.4 & 15.4 \\
Postgraduate & 7.1 & 7.0 & 7.1 \\
\hline
\end{tabular}


African Population Studies, Vol. 28, No. I, April 2014

\begin{tabular}{|l|l|l|l|}
\hline Faculty & & & \\
Human \& Social Sciences Scriculture, Science \& & 19.0 & 32.5 & 28.8 \\
Technology & 33.3 & 24.6 & 26.9 \\
$\begin{array}{l}\text { Commerce } \\
\text { Education }\end{array}$ & 28.6 & 21.9 & 23.7 \\
Law & 7.1 & 5.3 & 5.8 \\
\hline Home residence & 11.9 & 15.8 & 14.7 \\
Rural & & & \\
Urban & 71.4 & 56.1 & 60.3 \\
\hline Residence at the university & 28.6 & 43.9 & 39.7 \\
$\begin{array}{l}\text { On campus } \\
\text { Renting a room }\end{array}$ & & & \\
Other & 31.0 & 36.0 & 34.6 \\
& 31.0 & 28.1 & 28.8 \\
\hline Survival status of biological & 38.1 & 36.0 & 36.5 \\
parent & & & \\
Both alive & 66.7 & 68.4 & 67.9 \\
Other & 33.3 & 31.6 & 32.1 \\
\hline Total & $\mathrm{N}=42$ & $\mathrm{~N}=1 \mathrm{I} 4$ & $\mathrm{~N}=156$ \\
& $\%=100$ & $\%=100$ & $\%=100$ \\
\hline
\end{tabular}

experienced) whereas females delay first sex (the median age at first sexual intercourse is 18 years). This pattern is similar to that observed at both the Universities of Venda and Botswana (Anyanwu et al., 20I3; Hoque et al., 20I I). Figure I presents the box plot of age at first intercourse by gender for Mahikeng university students. The box for females is shorter and elevated than that for males. This suggests the delay for females and depicts the fact that most females initiate first sex at around the same time compared to males. The interesting part of the box plot is that the median is at the middle for both groups meaning that age at first intercourse is approximately normally distributed for both males and females.

\section{Age at first intercourse}

The analysis shows that males initiate sexual intercourse early (by age 16 half of them are sexually

Figure I: The box plot of age at first intercourse by gender

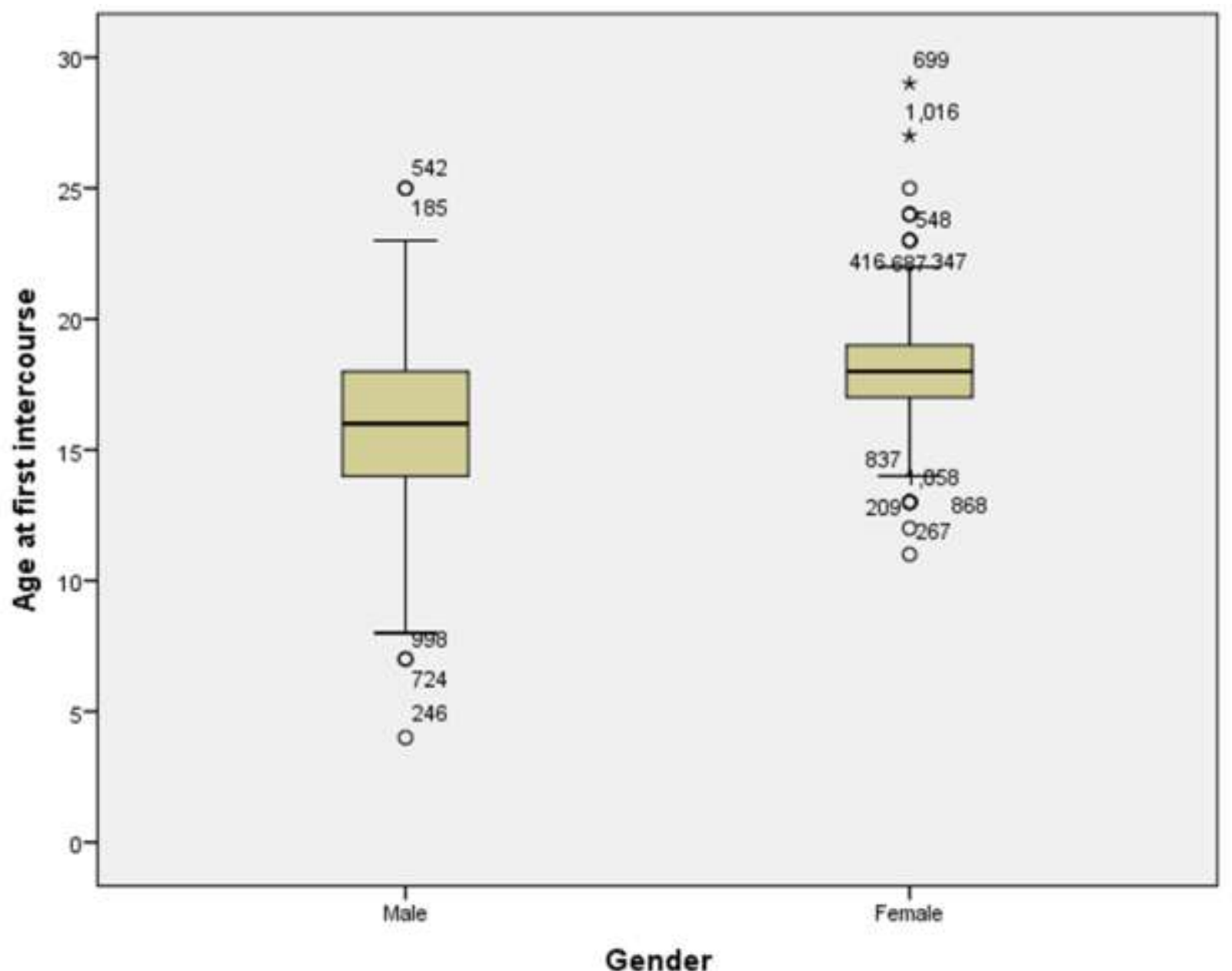

Another way of comparing male and female respondents' initiation of sexual activities is by looking at the Kaplan-Meier curve (Figure 2). Some females and males initiate sexual activities by age 10 . The curves show that the pace for male is much faster than that of females. By early twenties, all 
individuals in both groups become sexually

experienced.

Figure 2: Kaplan-Meier curve showing age at first intercourse by gender

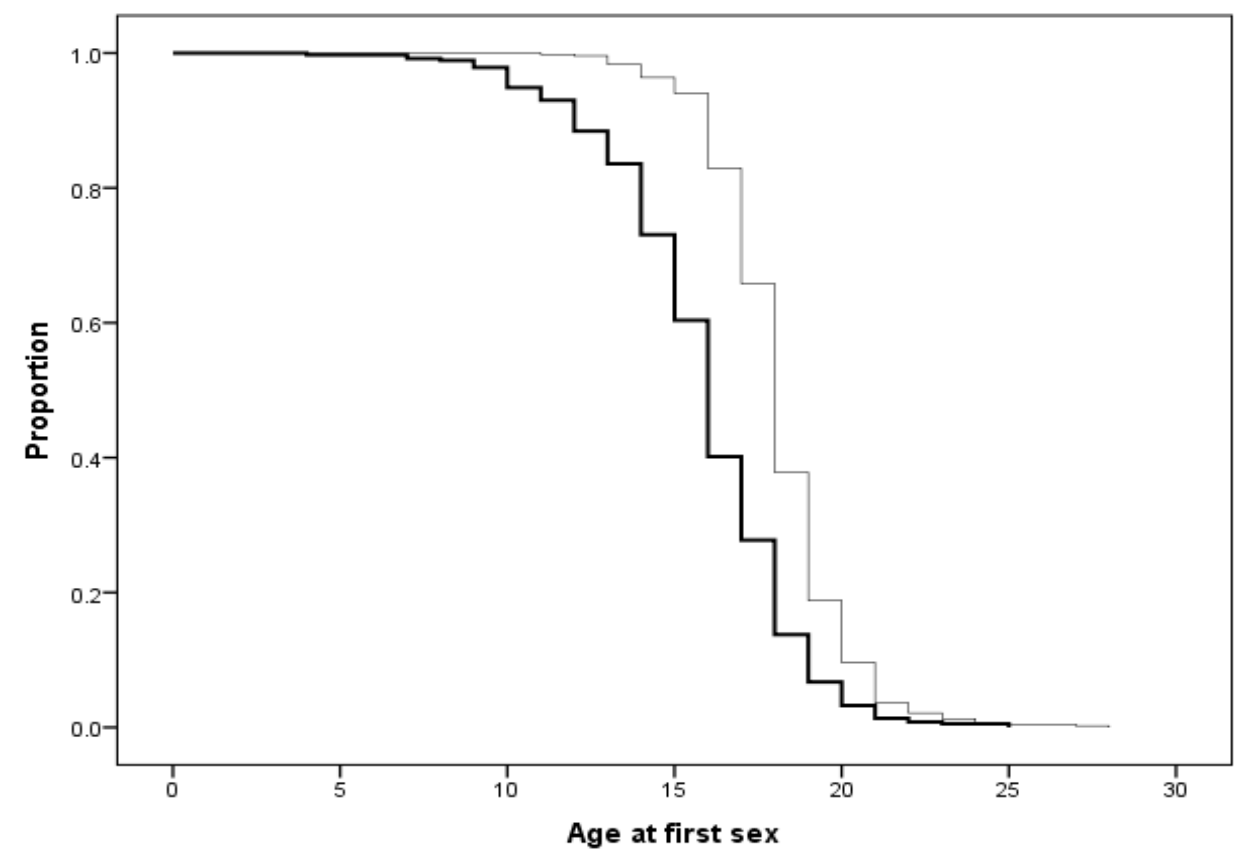

Table 3 reveals that the majority of students (73.0\%) initiated first sex before joining the university, but a substantial proportion of females $(33.8 \%)$ lost their virginity while on campus. Only $9.3 \%$ of males reported that they were not sexually experienced before they joined the university. The results also indicate that over half of the male respondents lost their virginity by the time they finished secondary school compared with under one-third of females. These findings suggest that females are more exposed to first sex on campus compared with males who join the university while already sexually active. Use of a condom at first intercourse was much higher for females (86.4\%) compared to their male counterparts (62.4\%). Over two-thirds of both males and females intended to have first sex and it seems alcohol consumption was not responsible for first sexual encounter as very few reported to have consumed alcohol before first sex took place.

The majority of respondents reported that they had first sexual intercourse with their intimate partner, the proportion of females (94.1\%) being higher than that of males (65.9\%). And there was no anticipation of getting any reward for initiating first sex. A significant number of respondents believed that their friends and peers were sexually active by the time they were having their first sex. Most females had their first sex at their partner's home whilst males had their first sex at their home. This means first sex usually takes place in male's residence.

The multivariate analysis of the factors related to first sexual intercourse is presented next. This is important in order to find out if sex was still an important factor in influencing first intercourse after controlling for other factors. Results are presented in Table 4. Along with gender, four other variables have been selected for this analysis (type of place of residence for the home place, education level at first sex, survival status of parents at first sex, and friends were sexually active at first sex). The findings show that gender is still significantly related to age at sexual intercourse. It is confirmed that male respondents are more likely to have a younger age at first intercourse than their female counterparts after controlling for selected factors. Of the selected variables, only educational level was found to be significant. That is, age at first intercourse was negatively related to education level. The model presented in Table 4 explains age at first intercourse 
African Population Studies, Vol. 28, No. I, April 2014

by $65 \%$ despite the fact that only two variables (gender and educational level) were significant.

Table 3: $\quad$ The percentage distribution of respondents by factors that may predispose them to first sexual debut by sex

\begin{tabular}{|c|c|c|c|}
\hline Characteristics & Male & Female & Total \\
\hline \multicolumn{4}{|l|}{ Level of education at first intercourse } \\
\hline Primary & 15.6 & 1.2 & 7.8 \\
\hline Secondary & 39.6 & 9.3 & 23.0 \\
\hline High & 33.5 & 49.4 & 42.2 \\
\hline Tertiary & 9.3 & 33.8 & 22.7 \\
\hline Other & 2.0 & 6.2 & 4.3 \\
\hline \multicolumn{4}{|l|}{ Use of condom at first sex } \\
\hline Yes & 62.4 & 86.4 & 75.6 \\
\hline No & 37.6 & 13.6 & 24.4 \\
\hline \multicolumn{4}{|l|}{ Intake of alcohol hours before first intercourse } \\
\hline Yes, I had some alcohol & 9.6 & 2.2 & 5.5 \\
\hline Yes, my partner had some alcohol & 0.5 & 3.0 & 1.9 \\
\hline Yes, both of us had some alcohol & 4.9 & 2.4 & 3.6 \\
\hline No, none of us had some alcohol & 70.8 & 72.8 & 71.9 \\
\hline Do not drink & 11.0 & 18.3 & 15.0 \\
\hline Do not remember & 3.2 & 1.2 & 2.1 \\
\hline \multicolumn{4}{|l|}{ Was first intercourse intentional } \\
\hline Yes & 68.1 & 70.9 & 69.6 \\
\hline No & 17.9 & 20.6 & 19.4 \\
\hline Do not remember & 14.0 & 8.6 & 11.0 \\
\hline \multicolumn{4}{|l|}{ Was first intercourse with a boy/girl friend? } \\
\hline Yes & 65.9 & 94.1 & 81.3 \\
\hline No & 34.1 & 5.9 & 18.7 \\
\hline \multicolumn{4}{|l|}{ Promise of rewards at first intercourse? } \\
\hline Yes, I was promised some rewards & 2.7 & 0.8 & 1.7 \\
\hline Yes, I promised my partner some rewards & 1.2 & 0.0 & 0.6 \\
\hline No rewards promised & 90.9 & 97.4 & 94.5 \\
\hline Do not remember & 5.1 & 1.8 & 3.3 \\
\hline \multicolumn{4}{|l|}{ Friends already sexually active? } \\
\hline Yes & 61.0 & 70.9 & 66.4 \\
\hline No & 17.0 & 14.1 & 15.4 \\
\hline Do not remember & 22.0 & 15.1 & 18.2 \\
\hline \multicolumn{4}{|l|}{ Place where intercourse took place? } \\
\hline My home & 40.7 & 9.3 & 23.5 \\
\hline My partner's home & 18.7 & 46.7 & 34.1 \\
\hline At a friend's home & 25.0 & 9.1 & 16.3 \\
\hline At my partner's rented place & 5.4 & 19.9 & 13.3 \\
\hline University residence & 3.4 & 6.5 & 5.1 \\
\hline Other & 6.6 & 8.5 & 7.7 \\
\hline \multicolumn{4}{|l|}{ Biological parents still alive at first intercourse? } \\
\hline Both alive & 75.9 & 70.8 & 73.1 \\
\hline Other & 24.1 & 29.2 & 26.9 \\
\hline Total & $\begin{array}{l}N=409 \\
\%=100\end{array}$ & $\begin{array}{l}N=494 \\
\%=100\end{array}$ & $\begin{array}{l}N=903 \\
\%=100\end{array}$ \\
\hline
\end{tabular}

Source: Mahikeng Sexual Behaviour Survey, 2013

Table 4: Ordinary least squares regression coefficients for the determinants of age at first intercourse

\begin{tabular}{|l|l|l|l|}
\hline Variable & \multicolumn{3}{|c|}{ COEFFICIENTS } \\
& Standardized Unstandardised Standard errors \\
\hline $\begin{array}{l}\text { Gender } \\
\text { O female I male }\end{array}$ & -0.070 & $-0.353^{* *}$ & 0.120 \\
\hline
\end{tabular}




\begin{tabular}{|c|c|c|c|}
\hline $\begin{array}{l}\text { Type of place of residence } \\
0 \text { urban I rural }\end{array}$ & -0.010 & -0.050 & 0.105 \\
\hline Survival status of parents & & & \\
\hline both alive & -0.033 & -0.183 & 0.230 \\
\hline only mother alive & -0.031 & -0.204 & 0.255 \\
\hline only father alive & -0.026 & -0.310 & 0.325 \\
\hline $\begin{array}{l}\text { Friends were sexually active } \\
0 \text { no I yes }\end{array}$ & 0.002 & 0.010 & 0.111 \\
\hline Educational level at first sex & & & \\
\hline primary & -0.827 & $-7.832^{* *}$ & 0.318 \\
\hline secondary & -0.763 & $-4.528^{* *}$ & 0.273 \\
\hline high school & -0.603 & $-3.045^{* *}$ & 0.254 \\
\hline tertiary & -0.160 & $-0.935^{* *}$ & 0.263 \\
\hline $\begin{array}{l}\text { Constant } \\
R^{2} \text { (adjusted) }=65 \%\end{array}$ & - & $\begin{array}{l}20.59^{* *} \\
-\end{array}$ & $\begin{array}{l}0.338 \\
-\end{array}$ \\
\hline
\end{tabular}

Source: Mahikeng Sexual Behaviour Survey, 20I3

Note: ** significant at 0.01 level

\section{Recent sexual activities on campus}

Some students (or young people in general) initiate sexual activities and stop having sex for one reason or another. Most of them continue practising sex. In this study $88.7 \%$ of the 904 students who ever had sexual intercourse were sexually active meaning that the proportion of sexually inactive students was only 11.3\%. Of those who were sexually active, $45 \%$ were males and $55 \%$ were females. Table 5 presents the characteristics of sexually active students by gender. Most of these students were having a boy- or a girl-friend, females (82.1\%) had a higher proportion of those in such relationship than males $(66.5 \%)$. A small proportion of the sexually active students were married at the time of the survey (6.1\% for females and $4.4 \%$ for males). As expected, the proportion was higher for males who reported to have casual partners as compared to females. The results in the table indicate that most male and female students had steady sexual relationships. Whilst the overwhelming majority of males had a sexual partner who was under 25 years old, the majority of females had partners who were in the age range of 17-24 and 25-31 years.

It is interesting to note that the majority of sexually active students did not expect any rewards from their partners as has been reported in literature. In addition, most students (females had a lower proportion than males) reported that they did not take any alcohol during the last sexual act. On initiating sexual activities in relationships, $74.6 \%$ of females and $59.1 \%$ of males reported that it had to be a joint decision. Whilst one third of males said they initiated sexual activities, almost one fifth of females reported that their partners initiated sexual activities. This means there is gender imbalance in initiating sexual activities. However a different pattern is observed on taking part in using a condom. The majority of both males and females reported that they take part in the decision to use or not to use a condom.

There were a number of factors included in the table that show the extent of indulging into risky sexual activities. The first is use of condom at the last sexual intercourse. Three-quarters of males and two-thirds of females used a condom during the last sexual act. Given that over $90 \%$ are not yet married, these proportions look encouraging but there is a room for improvement especially for females. Whilst half of the sexually active males admitted to have had a once-off sexual act with a total stranger in the past, only $16.1 \%$ of females reported doing so. There is a possibility that some of the female participants may have underreported for one reason or another however, the proportion for males was quite high. There were two more variables where male students performed terribly, namely 'had more than one boy/girlfriend at the same time' and 'intercourse with another person while in a relationship'. Even for females the idea of having multiple sexual partners was not uncommon. However, the challenge of 'sugar daddies' and 'sugar 
mommies' is not very common on this campus. Only $15.3 \%$ of males and $10.1 \%$ of females reported to be in a sexual relationship mainly to gain material things. All in all, risky sexual behaviour seems to be prevalent on this campus and males are more likely to engage in risky sexual behaviour than females.

Table 5: Selected factors on recent sexual activities of respondents by gender

\begin{tabular}{|c|c|c|c|}
\hline Characteristics & $\begin{array}{l}\text { Male } \\
(N=36 I)\end{array}$ & Female $(N=44 I)$ & Total $(\mathbf{N}=\mathbf{8 0 2})$ \\
\hline $\begin{array}{l}\text { Relationship to the recent sexual partner } \\
\text { Husband/Wife } \\
\text { Cohabiting partner } \\
\text { Boy/girlfriend } \\
\text { Casual partner } \\
\text { Other }\end{array}$ & $\begin{array}{l}4.4 \\
7.2 \\
66.5 \\
17.5 \\
4.4\end{array}$ & $\begin{array}{l}6.1 \\
4.8 \\
82.1 \\
5.7 \\
1.4\end{array}$ & $\begin{array}{l}5.4 \\
5.9 \\
75.1 \\
11.0 \\
2.7\end{array}$ \\
\hline $\begin{array}{l}\text { Age group of recent sexual partner } \\
17-24 \\
25-31 \\
32-39 \\
40+\end{array}$ & $\begin{array}{l}86.1 \\
8.6 \\
3.3 \\
1.9\end{array}$ & $\begin{array}{l}51.9 \\
35.4 \\
9.1 \\
3.6\end{array}$ & $\begin{array}{l}67.3 \\
23.4 \\
6.5 \\
2.9\end{array}$ \\
\hline $\begin{array}{l}\text { Use of condom at last sexual intercourse } \\
\text { Yes } \\
\text { No }\end{array}$ & $\begin{array}{l}76.5 \\
23.5\end{array}$ & $\begin{array}{l}65.5 \\
34.5\end{array}$ & $\begin{array}{l}70.4 \\
29.6\end{array}$ \\
\hline $\begin{array}{l}\text { Promise of rewards at last intercourse } \\
\text { Yes I was promised some rewards } \\
\text { Yes I promised my partner some rewards } \\
\text { No rewards promised } \\
\text { Don't remember }\end{array}$ & $\begin{array}{l}4.7 \\
1.7 \\
90.8 \\
2.8\end{array}$ & $\begin{array}{l}0.5 \\
0.2 \\
97.7 \\
1.6\end{array}$ & $\begin{array}{l}2.4 \\
0.9 \\
94.6 \\
2.1\end{array}$ \\
\hline $\begin{array}{l}\text { Intake of alcohol in the last intercourse } \\
\text { Yes } \\
\text { No }\end{array}$ & $\begin{array}{l}17.5 \\
82.5\end{array}$ & $\begin{array}{l}9.4 \\
90.6\end{array}$ & $\begin{array}{l}13.0 \\
87.0\end{array}$ \\
\hline $\begin{array}{l}\text { Sexual intercourse with more than one person last year } \\
\text { Yes } \\
\text { No }\end{array}$ & $\begin{array}{l}55.2 \\
44.8\end{array}$ & $\begin{array}{l}26.0 \\
74.0\end{array}$ & $\begin{array}{l}39.2 \\
60.8\end{array}$ \\
\hline $\begin{array}{l}\text { Ever had once off act with a stranger } \\
\text { Yes } \\
\text { No }\end{array}$ & $\begin{array}{l}50.1 \\
49.9 \\
\end{array}$ & $\begin{array}{l}16.1 \\
83.9\end{array}$ & $\begin{array}{l}31.6 \\
68.4\end{array}$ \\
\hline $\begin{array}{l}\text { Initiator of sexual activities } \\
\text { myself } \\
\text { my partner } \\
\text { Both }\end{array}$ & $\begin{array}{l}33.6 \\
7.3 \\
59.1\end{array}$ & $\begin{array}{l}6.0 \\
19.4 \\
74.6\end{array}$ & $\begin{array}{l}17.8 \\
14.2 \\
68.0\end{array}$ \\
\hline $\begin{array}{l}\text { Taking part in decisions of using a condom } \\
\text { Yes } \\
\text { No }\end{array}$ & $\begin{array}{l}92.5 \\
7.5\end{array}$ & $\begin{array}{l}92.5 \\
7.5\end{array}$ & $\begin{array}{l}92.5 \\
7.5\end{array}$ \\
\hline $\begin{array}{l}\text { Had more than one boy/girlfriend at the same time } \\
\text { Yes } \\
\text { No }\end{array}$ & $\begin{array}{l}60.1 \\
39.9\end{array}$ & $\begin{array}{l}28.7 \\
71.3\end{array}$ & $\begin{array}{l}42.6 \\
57.4\end{array}$ \\
\hline $\begin{array}{l}\text { Intercourse with another person while in a relationship } \\
\text { Yes } \\
\text { No }\end{array}$ & $\begin{array}{l}65.1 \\
34.9\end{array}$ & $\begin{array}{l}33.9 \\
66.1\end{array}$ & $\begin{array}{l}47.9 \\
52.1\end{array}$ \\
\hline $\begin{array}{l}\text { Ever had a relationship mainly to gain material things } \\
\text { Yes } \\
\text { No }\end{array}$ & $\begin{array}{l}15.3 \\
84.7\end{array}$ & $\begin{array}{l}10.1 \\
89.9\end{array}$ & $\begin{array}{l}12.4 \\
87.6\end{array}$ \\
\hline
\end{tabular}

Source: Mahikeng Sexual Behaviour Survey, 2013

Factors associated with risky sexual behaviour

Risky sexual behaviours on campus are mainly activities that expose students to sexually transmitted infections including HIV. In addition, exposure to unwanted pregnancies can also be categorised as risky sexual behaviour. The measurement of risky sexual behaviour is based on questions such as recent use of condoms, having sexual intercourse with multiple partners, experiencing a once-off sexual act with a casual partner, and paying or being paid for sexual favours. The dependent variable is therefore a composite variable formed by combining six variables and has three outcomes. A student is at high risk if she/he 
did not use a condom in the last sexual encounter and has previously had a once-off sexual act with a stranger or had an experience of having multiple sexual partners or had sex or relationship in anticipation of material things. The low risk is when a student was not involved in any risky sexual activities regardless of his/her condom use status. And no risk occurs for those who have never had sexual intercourse or are sexually experienced but have not had sexual intercourse in the last twelve months. The factors associated with indulging into risky sexual activities were investigated using the multinomial logistic regression analysis, since the dependent variable has three outcomes. There are seven independent variables that were selected for this analysis. The main variable investigated is gender and the control variables are age, faculty registered, year of study, type of home residence, survival status of parents and residence while at the University. The results are presented in Table 6.

Table 6: Multinomial logistic regression models on risk sexual behaviour

\begin{tabular}{|c|c|c|}
\hline Characteristics & Low risk & High risk \\
\hline $\begin{array}{l}\text { Gender } \\
\text { Female } \\
\text { Male }\end{array}$ & $\begin{array}{l}1.00 \\
0.81(0.26)\end{array}$ & $\begin{array}{l}1.00 \\
0.28 * *(0.23)\end{array}$ \\
\hline $\begin{array}{l}\text { Age group of respondent } \\
18-20 \\
21-23 \\
24+\end{array}$ & $\begin{array}{l}1.00 \\
0.18^{* *}(0.53) \\
0.37^{*} \\
(0.50)\end{array}$ & $\begin{array}{l}1.00 \\
0.19 * *(0.49) \\
0.38^{*}(0.48)\end{array}$ \\
\hline $\begin{array}{l}\text { Faculty registered } \\
\text { Human and Social Sciences } \\
\text { Agriculture, Science and } \\
\text { Technology } \\
\text { Commerce and Administration } \\
\text { Education } \\
\text { Law }\end{array}$ & $\begin{array}{l}1.00 \\
1.64(0.36) \\
0.80(0.37) \\
1.19(0.37) \\
1.57(0.52)\end{array}$ & $\begin{array}{l}\text { I.00 } \\
\text { I.65(0.34) } \\
0.71(0.34) \\
\text { I.03(0.34) } \\
\text { I.50(0.48) }\end{array}$ \\
\hline $\begin{array}{l}\text { Year of study } \\
\text { First } \\
\text { Second } \\
\text { Third } \\
\text { Postgraduate }\end{array}$ & $\begin{array}{l}1.00 \\
0.50(0.46) \\
0.96(0.47) \\
0.90(0.45)\end{array}$ & $\begin{array}{l}1.00 \\
0.58(0.43) \\
1.14(0.44) \\
1.78(0.43)\end{array}$ \\
\hline $\begin{array}{l}\text { Type of home residence } \\
\text { Rural } \\
\text { Urban }\end{array}$ & $\begin{array}{l}1.00 \\
0.90(0.22)\end{array}$ & $\begin{array}{l}1.00 \\
0.8 \mathrm{I}(0.2 \mathrm{I})\end{array}$ \\
\hline $\begin{array}{l}\text { Survival status of parents } \\
\text { Both alive } \\
\text { Other }\end{array}$ & $\begin{array}{l}1.00 \\
0.89(0.23)\end{array}$ & $\begin{array}{l}1.00 \\
0.90(0.21)\end{array}$ \\
\hline $\begin{array}{l}\text { Residence at the University } \\
\text { On Campus } \\
\text { Rent a room } \\
\text { Other }\end{array}$ & $\begin{array}{l}1.00 \\
2.40 * *(0.27)\end{array}$ & $\begin{array}{l}1.00 \\
2.35 * *(0.25)\end{array}$ \\
\hline
\end{tabular}

\begin{tabular}{|l|l|ll|}
\hline & $1.80 *(0.29)$ & 1.56 & $(0.26)$ \\
\hline Constant & $6.55 * *(0.66)$ & $22.89 * *(0.66)$ \\
\hline
\end{tabular}

Source: Mahikeng Sexual Behaviour Survey, 2013

Note: * significant at 0.05 level; ** significant at 0.0 I level

Gender has a very interesting relationship with risky sexual behaviour. There is no significant difference between males and females in indulging into low risk activities before (results not shown) and after controlling for other factors. However, males are $72 \%$ less likely to indulge in high sexual risk activities compared to females after controlling for other factors. This relationship is significant at $1 \%$ level. At face value this sounds implausible but given that males use condoms more than females, it makes a lot of sense. However, apart from no-use of condoms, females do not practise other risky sexual behaviours more than males. It is important to observe that not using condoms exposes them to acquiring STIs and getting pregnant.

There are two more factors that were found to be significant - age of respondent and residence at the university. Older students were less likely to indulge in risky sexual behaviours than younger students. This is true for both low and high risk activities. It would appear that younger students are still enjoying themselves in an irresponsible manner. As for residence at the University, students who rent a room off campus indulge in risky sexual activities more than those staying on campus. For low risk, the magnitude was 2.40 times and for high risk it was 2.35 times, and both were significant at I\% level. These results are expected. There are somewhat restrictions on campus like times for visitors, some limits on social parties, drinking, etc. But in most cases private accommodation are not as restrictive. Other types of accommodation (such as staying with parents or relatives) are significant for low risk but not for high risk. All in all, it can be said that campus accommodation is relatively the best in terms of students being involved in risky sexual behaviours. Faculty where students are registered, year of study, type of home residence, and survival status of parents are not found to be significant despite high coefficients.

\section{Summary and Conclusion}

This study investigated the gender differences in sexual activities on campus in Mahikeng, South Africa. It had three objectives: to examine the characteristics of male and female university students who had never had sexual intercourse; to 
assess the factors associated with age at first intercourse for males and females; to examine factors associated with risky sexual behaviour and whether they are different for male and female students.

A cross-sectional study was conducted on campus where 1060 students (45I males and 609 females) successfully filled-in a structured questionnaire. The analysis involves tabular and graphical analyses, multiple OLS regression and multinomial logistic regression.

The results show that 156 students $(14.7 \%$ of the sample) were still virgins and the proportion of females was much higher than that for males. Surprisingly, most of these respondents were in stable sexual relationships. The average age at first sexual intercourse was 16 years for males and 18 years for females. The multivariate analysis shows that gender and education are significant determinants of age at first sexual intercourse. Furthermore, the analysis on risky sexual behaviour indicates that males are less likely to indulge in risky sexual activities compared to their female counterparts. This is partly because a higher proportion of females do not use condoms. Risky sexual behaviour is also related to age of respondent and where students stay while attending classes. Younger students and those who rent a room off campus are more likely to indulge into risky sexual activities than other students.

These findings have a number of policy implications. The existing programme on the NWU_MC that focuses only on HIV awareness needs to be expanded, so that it can deal with the broad area of sexuality and sexual behaviour of students. Students should be exposed to sex related information on arrival at campus, and get the required support when necessary as they pursue their studies. The problem of inadequate accommodation on South African university campuses is well known. The alternative has been to get a private room off campus. But it seems there are implications in terms of making those students indulge in 'irresponsible' sexual activities. Universities should continue to look for a solution to this problem, which ensures that all students who want to stay on campus get a room at the University residence.

Further research is needed that looks closely into how to design programmes that assist students with sexual related matters on campuses. At the moment sexual issues are encompassed with the HIV/AIDS programme in many Universities which are in most cases very weak. Unless programmes are designed properly on campuses, students will continue to have difficult times in dealing with unwanted pregnancies, induced abortions, STls including HIV/AIDS, poor performance and drop outs. Unfortunately, females are the most affected in these issues than males.

Acknowledgement

Authors wish to acknowledge financial support provided to Lucia Gaearwe from the Research Niche Area 'Population and Health' (North-West University) and the National Research Foundation of South Africa.

\section{References}

Amoateng,AC and Kalule-Sabiti, I (2013). "Social structure and sexual behaviour of black adolescents in the North West Province, South Africa."South African Review of Sociology, 44(I): |3|-157.

Anyanwu, FC, Goon, DT and Tugli, A (2013). "Socio-demography and sexual experiences of University of Venda students: Implications for health." African Journal for Physical, Health Education, Recreation and Dance, 19(2): 459478.

Fisher, TD (2007). "Sex of experimenter and social norm effects on reports of sexual behaviour in young men and women." Achieves of Sexual Behaviour, 36(I): 89-100.

Gilchrist, H, Smith, K, Magee, CA and Jones, S (2012). "A hangover and a one-night stand: Alcohol and risky sexual behaviour among female students at an Australian University." Youth Studies Australia, 3 I (2): 35-43.

Gueye, M, Castle, S and Konate, KM (200I). "Timing of first intercourse among Malian adolescents: Implications for contraceptive use." International Family Planning Perspectives, 27(2): 56-62.

Haggstrom-Nordin, E, Hanson, $U$ and Tyden, T (2002). "Sex behaviour among high school students in Sweden: Improvement in contraceptive use over time." Journal of Adolescent Health, 30(4): 288-295.

Hoque, ME (20II). "Sexual practices among male undergraduate students in KwaZulu-Natal, South Africa." South African Journal of Epidemiology and Infection, 26(3): 157-160. 
Hoque, ME, Ntsipe, T and Mokgatle-Nthabu, M (20/2). "Sexual practices among University students in Botswana." Gender and Behaviour, 10(2): 4646-4656.

Kabir, M, Lliyasu, Z, Abubakar, I and Kabir, AS(2004). "Sexual behavior among students in tertiary institutions in Kano, Northern Nigeria". Journal of Community Medicine \& Primary Health Care, I6(2), I7-22.

Khasakhala, A and Mturi, AJ (2008) "Factors associated with risky sexual behaviour among out of school youth in Kenya." Journal of Biosocial Science, 40(5): 64I-653.

Ngoma, CM and Himoonga, UM (2010). "Gender differences in sexual behaviours among students at the University of Zambia, Lusaka." African Journal of Nursing and Midwifery, I2(2): 27-35.

Njikam-Savage, OM (2005). "Risky sexual behaviour, sexually transmitted infections, HIV/AIDS and health promotion among students in the University of Douala." African Population Studies, 20(I): 53-67.
Ojedokun, AO and Balogun, SK (2008). "Gender differences premarital sexual permissiveness among university undergraduates." Gender and Behaviour, 6(1): 165I-1672.

Olley, BO (2008). "Child sexual abuse, harmful alcohol use and age as determinants of sexual risk behaviours among Freshmen in a Nigerian University." African Journal of Reproductive Health, 12 (2): 75-88.

Omoteso, BA (2006). "A study of the sexual behaviour of university undergraduate students in Southwestern Nigeria." Journal of Social Sciences, 12(2): 129-133.

O'Sullivan, LF, Harrison, A, Morrell, R, MonroeWise, $A$ and Kubeka, M(2006). "Gender dynamics in the primary sexual relationships of young rural South African women and men." Culture, Health \& Sexuality, 8(2): 99-II 3.

Zambuko, O and Mturi, AJ (2005). "Risk sexual behaviour among the youth in the era of HIV/AIDS in South Africa." Journal of Biosocial Science,35(5): 569-584. 